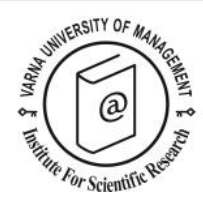

\title{
Sustainable authenticity in a World Heritage Site: The Maritime Greenwich example
}

\author{
Azizul Hassan ${ }^{1}$ and Erdogan Ekiz ${ }^{2 *}$
}

\footnotetext{
${ }^{1}$ Tourism Consultants Network, the Tourism Society, London SE1 oAA, UK; E-mail: azizulhassanoo@gmail.com

${ }^{2}$ Associate Professor, Mohammed VI Polytechnic University, School of Hospitality Business and Management, Morocco. E-mail: erdogan.ekiz@gmail.com

* Corresponding author
}

\begin{abstract}
The research is based on the Maritime Greenwich World Heritage Site (MGWHS) UK. UNESCO recognises a place as the World Heritage Site that presents 'Outstanding Universal Value'. This site is identified as a relevant case and suitable for necessary data collection by using face-to-face interviews, focus group discussions and personal observation. The objective of this study is to understand the requisite of technology application for modernisation in the WHS perspective that has authenticity and historical significance. Results outline that, authenticity and technology application can stay parallel to each other; these two aspects are fundamental to a WHS, when tourism is concerned. Thus, the research suggests that are very little scopes exist to ignore significance of both authenticity and technology adoption for modernisation. Also, due to set guidelines of the UNESCO WHS, an amiable standpoint of all these aspects is a possibility.
\end{abstract}

Keywords: authenticity, technology, modernisation, tourism, Greenwich

Citation: Hassan, A. and Ekiz, E. (2021). Sustainable authenticity in a World Heritage Site: The Maritime Greenwich example. European Journal of Tourism Research 28, 2804. 


\section{Introduction}

Within the paradigm of heritage tourism, recognition of a place as the World Heritage Site (WHS) by UNESCO represents 'Outstanding Universal Value' in terms of significance with its authenticity and historic importance. Tourism becomes an unavoidable part in this regard accompanying authentic and history excellence of a WHS. In particular, it is generally expected from the WHS management side that tourists visit such sites and contribute in their development. Such involvement of tourists means that technology application for modernisation deserves more attention with technology support. This becomes evident on theoretical ground, where 'authenticity seeking modern tourists' typically view modernity and tourism as intertwined with each other (MacCannell, 1973). In diverse study locale of Africa, researchers identified growing number of tourists seeking sustainable authenticity in heritage tourism sites and argue that perceived sustainable authenticity is attached with place satisfaction (Ramkissoon, 2015). On the other side, the process of technology application for modernisation to offer pleasant and memorable experience cannot be disregarded, where tourism is involved. Typically, sustainable authenticity and historic significance is valued less where, technology application for modernisation renders priority in the heritage tourism scenario. Research shows that for heritage tourism, immersive technology, such as augmented and virtual reality can create memorable tourism experiences (Bec et al., 2019). Still, modernisation initiatives in a place of historic and heritage can consequence to a conflict ground (Cohen, 2001). A heritage tourism site as the Maritime Greenwich having the UNESCO World Heritage Site brings honour followed by increased attention from tourists. These sites typically render historical importance. In such circumstance, the maintenance of authenticity in such sites turns into a challenge, when technology application for modernisation purposes is involved. In many cases, technology application for modernisation is seen as a threat towards authenticity. Still, due to increasing tourism activities, technology application for modernisation needs to be given adequate consideration. This study selects the Maritime Greenwich World Heritage Site (MGWHS) as a case considering it as the suitable and relevant case for this research. Research studies on the MGWHS so far have covered branding (e.g. Hassan, \& Rahman 2015a), and tourist facilities management (e.g. Hassan \& Iankova, 2012) and few other areas. However still with importance, the application of technology in an authentic heritage site as MGWHS has not been well researched. A research gap persists in this identified research area. Thus, this study is expected to contribute to this area of limited knowledge. The aim of the study is straightforward and that is to understand the requisite of technology application for modernisation in a WHS that comes with authenticity and historic importance. Also, the research explores the framework within which these interact with each other.

\section{Literature Review}

\section{The World Heritage Site status}

The World Heritage Site status is offered to a place, monument, building or even landscape on the ground of their 'outstanding universal value' (United Nations Educational, Scientific and Cultural Organization, 2019a). This organisation also provides outlines showing that the World Heritage Site status is offered on ground of the World Heritage Convention (WHC) that was signed up in 1972 by nations from all over the world to 'recognise, inventory, and protect unique and irreplaceable properties of universal value'. This accolade is presented with aims to promote significance of the site, better management and long-term improvement (Labadi, 2007). Designated areas with the World Heritage Site status are predominantly becoming tourist attractions in comparison with other areas (Millar, 1989). However, researchers find that the preserving the intangible cultural heritage (ICH) and meaningful co-creation are essential and without these, a WHS can lose its uniqueness (Ross, 2020; Tan et al., 2020). 


\section{Dynamics of modernisation}

Travel and tourism activities in Europe have passed through several centuries and are attached with the process of technology application for modernisation (Pack, 2008). The process of technology application for modernisation include industrial or social organizational changing patterns, the building of nations, increased consumption by the masses and tourist awareness (Bowitz \& Ibenholt, 2009). Technology application for modernisation process in Europe including the United Kingdom has inevitably helped to raise issues on general impacts of Technology application for modernisation on tourism sector (Harrison \& Hitchock, 2005; Lisagor \& Hansen, 2008). Technology application for modernisation as a process can render capacity to affect almost every part of human life with impacts, both positive and negative (Park et al., 2019). Conventionally, there have always been constant efforts to represent the process of technology application for modernisation through conceptual approaches (Giddens, 1991). That is, technology application for modernisation as the process of sustainable authenticity can have influences on the touristic experiences as well (Ram et al., 2016). Also, the ability of stakeholders for incorporating tourism culture is important and Pickel-Chevalier (2019) in this regard affirms that socio-cultural change by the stakeholders in WHS is useful. A more recent research reveals that, a positive correlation exists between sustainable authenticity and place attachment and places having more heritage experience is seen as more authentic (Carnegie, \& Mccabe, 2008).

\section{Historic significance}

In many cases, significance is called the forgotten concept in history because it can both influence the present and shape the future (Yung \& Chan, 2011). Historic significance is meant as the process applied for evaluating what has been significant in terms of some selected development, events and people in the past. For helping for making judgement about significance, diverse sets of criteria are used. Significance stays as the importance measurement that is assigned to developments, locations, events, groups and locations (Northern Ireland Council for Integrated Education, 2020). A specific location, site or development can be termed as significant because it has the capacity to bring important change in the history. The discovery of a location, site or development's causes and its consequences can help working out if it has significance or not. Historic significance is rather a decision that the people of modern age make out in terms of what is important in the past (English Heritage, 2008). For assigning historic importance particular locations, developments, ideas and people are chosen as being important. As significance is a decision that people make, this means that different people can decide that different things can be significant or even they can disagree about the reasons a specific location, development, place or people or idea is important. This can be one of the reasons historic significance is not similar to everyone. In terms of deciding historic significance, the four criteria (i.e. Novelty, applicability, memory, and effects) with acronym of "NAME" is applied (History Skills, 2020). A WHS like the Maritime Greenwich has historic significance in terms of architectural excellence.

\section{Sustainable authenticity and tourism}

Sustainable authenticity is not a new concept (Carnaffan, 2019). However, this remains a very ambiguous term within tourism literature (Steiner \& Reisinger, 2006; Wang, 1999). Even though there are tensions between authenticity, sustainability and neo-liberal development, the role of authenticity in the sustainable development discourse is important (Carnaffan, 2019). The concept of sustainable authenticity was introduced to sociological studies of tourist motivations and experiences (Carnaffan, 2019; MacCannell, 1976) and since became an important area of research (Albayrak \& Caber, 2019; Cohen, 2001; Martin, 2010; Moscardo \& Pearce, 1986); Agyeiwaah et al., 2017; Larsen, 1995). Following the 1994 Nara Documents on Sustainable authenticity, sustainable authenticity is about maintaining and clarifying the heritage values to establish a balance between them (McKercher \& du Cros, 2002). Tourists' quest for sustainable authenticity of the cultural tourism product has generated a wide debate 
on the definition of the term. Researchers argue that sustainable authenticity discourse is often subject to multiple perspectives. It has been apprehended differently by scholars and remains a contested term (Nguyena et al., 2019; Chhabra, 2008). One reason for this is the audience searching for experiences (Handler \& Saxton, 1988). Researcher described the search for the authentic cultural experience as 'the unspoiled, pristine, genuine, untouched and traditional' (Spooner, 1986, p.2). However, today's modern travelers' have become more sophisticated in ability and desire to experience sustainable authenticity. As pointed out that 'this has to do not only with genuineness and reliability, but with the interpretation of genuineness and our desire for it' (Rickley-Boyd, 2012, p. 200). This is further argued that this interpretation has started to move from a fascination with sustainable authenticity to an increased appreciation of the tourism object which is vital to the latter's success (Pearce, 1982).

Holidaying in a destination, with which an individual is familiar can offer a form of psychological period within which they can be recharged, regenerated and enriched by means of their own environment (Peter \& Olson, 1999). This may suggest that an authentic tourist destination can be genuine and undisturbed by its character. Also, in an authentic tourist destination, access to interpretation may be difficult in a sense, where the capacity of cognitive attitude resembles higher aspects (Reisinger \& Steiner, 2006). In such situations, all features of sustainable authenticity are difficult to be viewed as general, where the sense of negative aspects can be higher through the tourist unfamiliarity. Often, sustainable authenticity acts either as single or as the most influential motivation for tourists to visit a place (Tasci \& Knutson, 2004). Sustainable authenticity can be explored through comprehensive and pleasant experiences, where touristic understanding relies on numerous facts and issues (Larsen, 1995).

\section{Sustainable Authenticity Seeking Modern Tourists}

Researches or studies of the World Heritage sites are shifting from strict official management to more tourist experience generating format (Guttormsen \& Fageraas, 2011; Lew, 2011). In addition, the theme of sustainable authenticity is established and evidenced as in heritage studies. Dean MacCannell (1976) was the pioneer in discovering interrelation between modernity and tourism within the wider framework of sociological discourse. MacCannell (1976) believed that the modernists are regarded as aliens from the society belongs to them, where sustainable authenticity and reality are thought to be placed in historical times and in other cultures with the most basic simplicity of life patterns. In a general sense, sustainable authenticity seeking modern tourists combines the originality of touristic appeals with historic dynamics. However, this is suggested on the main grounds of culture and ecology that tourism should have more priority that may create interests among those peoples who generally look for sustainable authenticity in tourist areas (Cohen-Hattab \& Kerber, 2004). There has been a set interrelationship between time and place, where these two facts most likely work together (Conran, 2006). Sustainable authenticity as a term has managed to get more popularity during the decade of 1930s, however the extent of such popularity has changed over time and place. The notion of globalization was attached with sustainable authenticity with facts of distinctions, where sustainable authenticity rendered interrelationships with historical artefacts (Jokilehto, 2006; Alberts \& Hazen, 2010; Taylor \& Kirsty, 2006). This was also involved with diverse issues: gap between time and space as an obvious phenomenon in terms of discussion about sustainable authenticity. Following the growing influence of modernisation, sustainable authenticity as a concept has been constantly modifying that has allowed the policy planners to view sustainable authenticity from various and multiple angles. In a more sensible meaning, when sustainable authenticity is involved with mass conceptualization, there is always a tremendous effort to view this from numerous viewpoints and ideologies. Sustainable authenticity has formal unification with elements of identification (Steiner \& Reisinger, 2006). There is also a continuous trend that necessarily creates gaps between issues of identification and attached 
concerns about sustainable authenticity. This trend is more unlikely to be viewed as part of the cultural history and there is a given detachment between these two different facts.

Sustainable authenticity in tourism provides diversity and outlooks that shows that sustainable authenticity is related to objectives, where authentic experiences rely on originality and real scenario. Symbols those are involved with sustainable authenticity represent that touristic activities are closely shared with perceptions, preferences and perceived experiences (Lew, 2011). Types of sustainable authenticity vary in accordance with the demand of situation or circumstances and mainly with the real touristic experiences. Existentialist sustainable authenticity as a form is attached with the authentic status of an individual, where they are associated to experience sharing. Visitation to a historic place or site typically offers experience to the tourists that are generally different, history based and authentic.

Table 1. Authenticity typology and features

\begin{tabular}{ll}
\hline Sustainable Authenticity Typology & Key Feature \\
\hline Material sustainable authenticity & Characteristically changes the object in its own way \\
Conceptual sustainable authenticity & Changes the purpose \\
Contextual sustainable authenticity & Changes the environment \\
Functional sustainable authenticity & Changes the functions \\
\hline
\end{tabular}

(source: Taylor \& Kirsty, 2006).

Traditionally, sustainable authenticity follows at least four types (see Table 1). The interrelations between these four types of sustainable authenticity can become conflicting very often and less likely to be applicable to similar circumstances. Considering and understanding the historical situation, sustainable authenticity of all types cannot be viewed in the same pattern and in the same types. Phenomenon of the past can merely have viewed as traditional and as similar to the current situation or contexts (United Nations Educational, Scientific and Cultural Organization, 2019b).

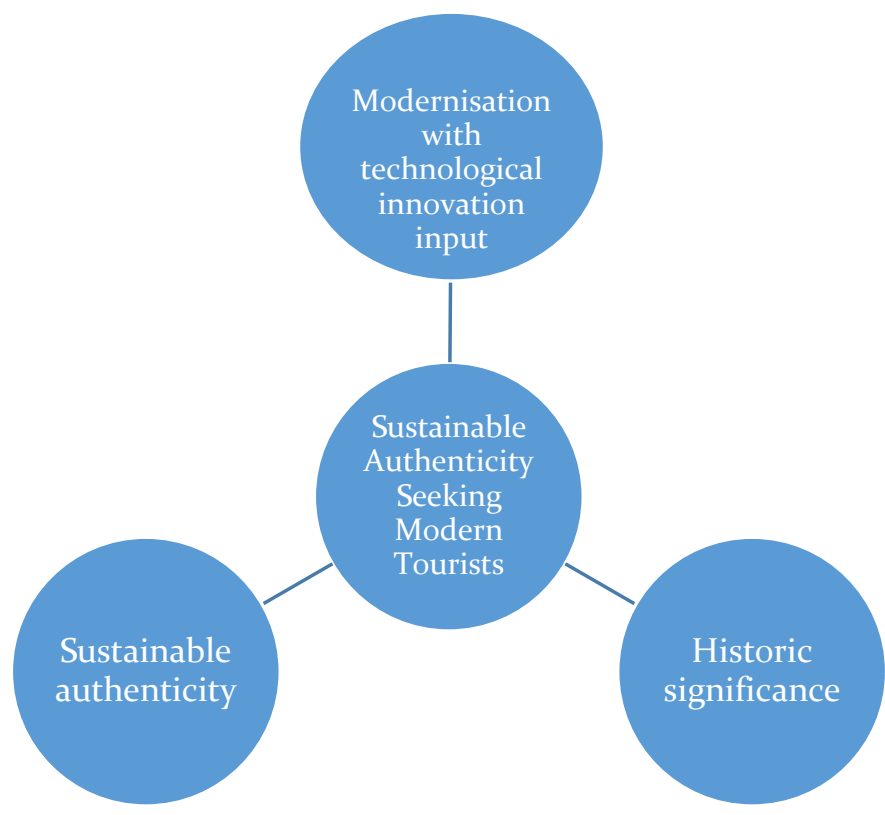

Figure 1. Conceptual framework of sustainable authenticity in a WHS (Source: emerged from this study). 
Figure 1 offers the visual aid and theoretical framework of the key concepts and findings as discussed in the following sections. Figure 1 shows that modernisation with technological input is in principle aimed at respecting historic significance and sustainable authenticity. This can perpetually encourage Sustainable Authenticity Seeking Modern Tourists to visit a WHS as the MGWHS.

\section{Methodology}

\section{Study Site}

The Maritime Greenwich World Heritage Site is located in the Royal Greenwich Borough of London. This site is considered as case for this study, due to better match for this study than the other WHSs in London. Improved transportation with better access of data and information collection procedures was also another factor to consider. The Maritime Greenwich is the United Kingdom's $15^{\text {th }}$ Cultural World Heritage Site declared in 1997 (Hassan \& Rahman, 2015a). This offers excellence in both historic and architectural value in its seventeenth and eighteenth century English structures. With contributions of Inigo Jones, Christopher Jones, Nicholas Hawskmoor and associates, the Maritime Greenwich is comprised of the Greenwich town centre, the Royal Park, the Queens House, and the Royal Hospital for seamen. Listing of the World Heritage Site is a complex process and passes through numerous considerable factors and issues. UNESCO listed the Maritime Greenwich as a WHS on basis of the selection criteria of $\mathrm{i}$, ii, iv and vi. The Maritime Greenwich is adorned with architectural excellence on the ground of historical landscape and in the Royal Borough of Greenwich. Located within this excellent urban setting, this WHS is authentic by character as considered by the UNESCO. On the other side, the Maritime Greenwich has been constantly facing challenges to cater demands of both the international and local tourists. This is often claimed that maintenance and protection of both the buildings and cultural heritage sites are appreciated as positive practice of the globally renowned status of the World Heritage Site (Hassan \& Rahman, 2015b; The National Maritime Museum, 2019). The Maritime Greenwich offers sustainable authenticity that can possibly be accompanied by immersive technology. There is always a tremendous possibility that specific groups of tourists like teenagers of generation $\mathrm{Y}$ can possibly like the technology penetrated heritage tourism experience. Involvement of an increased number of tourists can positively help to popularise the site across the world. However, the requirement for effective management becomes essential to avoid any likely negative consequence. There are evidences that the MGWHS has good reputation for filming.

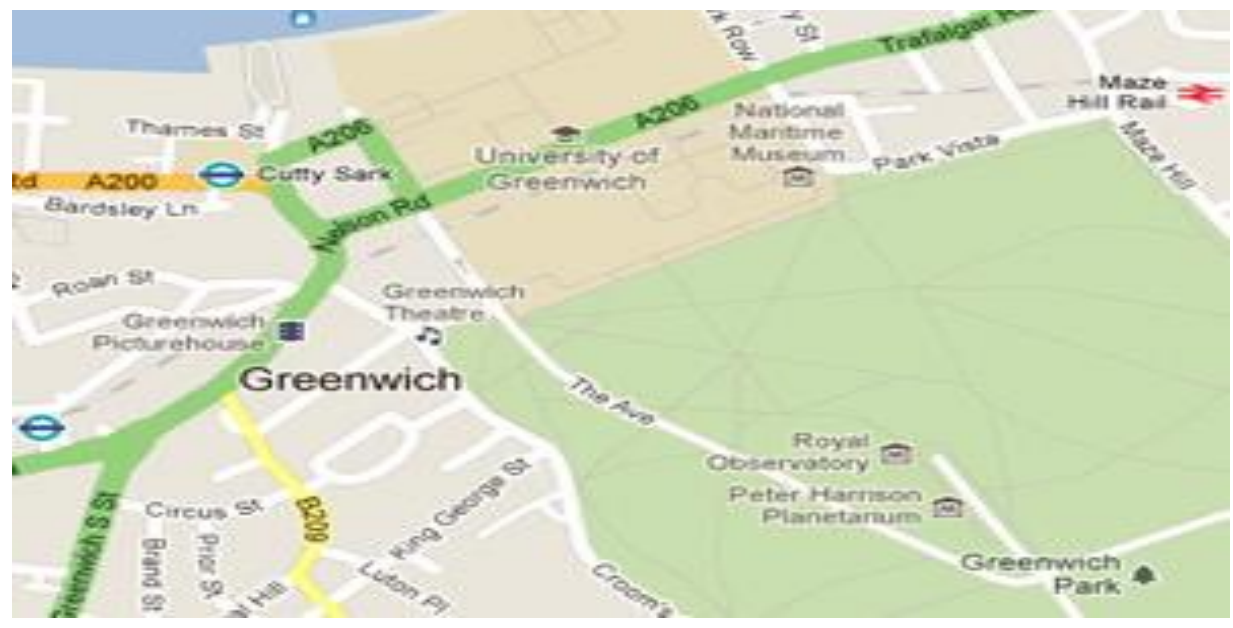

Figure 2. The Case Study Site - the Maritime Greenwich World Heritage Site (The National Maritime Museum, 2019). 
Figure 2 is the map of the MGWHS that is the case of this research.

\section{Research Design and Data Collection}

This study is designed with the qualitative methods of research (Merriam \& Grenier, 2019). In-depth interviews focus group discussions and personal observation with review of existing literatures were the main ways to generate data and information. Tourists coming to the site were defined as those tourists who were coming and staying at the site, while tourists leaving the site were defined as those who were departing the MGWHS after their visit.

A total of thirty interviews were conducted with three categories of respondents. Sample respondents were purposively selected. First, two interviews were conducted with two official respondents who represented the Greenwich Council and the Greenwich Foundation, respectively. These two respondents were the key informants having considerable knowledge about the MGWHS both from management and operational contexts. These informants were particularly asked about official viewpoint, set guidelines by the UNESCO for a World Heritage Site and their applications. Also, they were inquired about planning to meet demands of the tourists. Second, fourteen tourist respondents coming to the site and fourteen tourist respondents departing from site were interviewed. Tourists coming to the site were asked about their views on the three identified factors of sustainable authenticity, historic significance and modernised forms of visual and entertainments for the tourists. Third, based on their experiences in the case study site, the tourists leaving from the site were asked about their demands highlighting what they thought would be better addition to the site. These respondents were also asked about the facilities offered for the tourists and to which extent those can be identified as modernised and which ways they can be regarded as modernised. Table 2 shows the profile of the respondents.

Table 2. Respondents' profiles

\begin{tabular}{|c|c|c|c|c|c|c|c|c|c|}
\hline $\begin{array}{l}\text { Respondent } \\
\text { No }\end{array}$ & $\begin{array}{l}\text { Age } \\
\text { group }\end{array}$ & Gender & Nationality & Education & $\begin{array}{l}\text { Respondent } \\
\text { No }\end{array}$ & $\begin{array}{l}\text { Age } \\
\text { group }\end{array}$ & Gender & Nationality & Education \\
\hline $\mathrm{K}_{1}$ & $30-40$ & Female & British & Master & $\mathrm{K}_{2}$ & $40-50$ & Male & British & Master \\
\hline $\mathrm{R}_{1}$ & $30-40$ & Male & India & PhD & $\mathrm{S}_{1}$ & $50--60$ & Female & Australia & Master \\
\hline $\mathrm{R}_{2}$ & $20-30$ & Male & $\begin{array}{l}\text { United States } \\
\text { of America }\end{array}$ & Bachelor & $\mathrm{S}_{2}$ & $20-30$ & Female & Italy & Bachelor \\
\hline $\mathrm{R}_{3}$ & $50--60$ & Female & Argentina & Master & $\mathrm{S}_{3}$ & $20-30$ & Male & British & Bachelor \\
\hline $\mathrm{R}_{4}$ & $40-50$ & Male & British & Bachelor & $\mathrm{S}_{4}$ & $30-40$ & Female & British & Master \\
\hline $\mathrm{R}_{5}$ & $30-40$ & Female & India & Master & $\mathrm{S}_{5}$ & $50-60$ & Female & India & PhD \\
\hline R6 & $20-30$ & Male & Germany & Master & S6 & $50--60$ & Female & Nepal & School Leaver \\
\hline $\mathrm{R}_{7}$ & $30-40$ & Female & France & Master & $\mathrm{S}_{7}$ & $20-30$ & Male & British & Bachelor \\
\hline R8 & $30-40$ & Male & British & Bachelor & S8 & $20-30$ & Male & British & Bachelor \\
\hline $\mathrm{R}_{9}$ & $20-30$ & Female & New Zealand & Bachelor & S9 & $20-30$ & Female & Russia & Bachelor \\
\hline Rio & $40-50$ & Female & British & PhD & Sio & $40-50$ & Male & Bangladesh & $\mathrm{PhD}$ \\
\hline Rn1 & $20-30$ & Male & India & PhD & S11 & $30-40$ & Male & Bangladesh & Bachelor \\
\hline $\mathrm{R}_{12}$ & $20-30$ & Female & Ireland & Master & $\mathrm{S}_{12}$ & $40-50$ & Male & Saudi Arabia & Master \\
\hline $\mathrm{R}_{13}$ & $40-50$ & Female & Kuwait & Bachelor & $\mathrm{S}_{13}$ & $20-30$ & Male & Denmark & Master \\
\hline R14 & $40-50$ & Male & Argentina & PhD & $\mathrm{S}_{14}$ & $30-40$ & Female & Sweden & Master \\
\hline
\end{tabular}

Ten focus group discussions (FGD) were performed with groups of tourists both incoming and outgoing. Five tourist groups (i.e. three tourists in each group) coming to the site with randomly chosen nationality were selected, as well as similar number of tourists leaving the site. FGDs carefully addressed any embedded flow of groupthink by reducing the number of participants in each FGD. These discussions included different type of peoples and tourist groups. Themes of these discussions were the tourist views prior to their visit and demands based on their experiences after the visit. 
Duration of each of the in-depth interviews was between fifteen to twenty minutes followed by the semi-structured questionnaire. On the other side, each FGD was between fifteen to twenty minutes long and were conducted separately to the interviews. Both the all of the interviews and FGDs were recorded on the mini tape recorder; self-transcribed and then contents and themes were analysed and elaborated. As believed, the self-transcribing process usually better helps the researcher to go through contents of recorded contents. This also assists in exploring and understanding facts more intensively. All of the interviews and FGDs with the tourists were conducted in situ with no preferred specific spot of the case study site, where interviews with the key informants were conducted in their offices. Indepth interviews are classified as: for the first respondent group of key informant as $\mathrm{K}_{1}$ and $\mathrm{K}_{2}$; for the second respondent group of incoming tourists as R1-R14; and for the third respondent group of outgoing tourist as $\mathrm{S1-S14}$. Respondent selection ensured a proportionate representation of male and female as well as multi-nationalism, age group and academic background.

There has always been emphasis to explore in depth information. With this aim in mind and practice, intensive and thorough reviews on the existing literature studies and online resources were also carried out.

\section{Results and Discussion}

\section{The Maritime Greenwich World Heritage Site}

The Maritime Greenwich is the world's one of the most visited and popular sites in terms of visitor number. Respondent R1 who was knowledgeable about heritage tourism and originated from India and commented that 'this site represents a unique sign of architectural importance and appeal not only to the global heritage tourists, but also to the general public'. On the other side, the local British respondent $\mathrm{R}_{4}$ argued that, 'this site can have diverse pleas to the global tourists and thus to motivate them to visit. The outgoing respondent S1 form Australia viewed that, 'the Maritime Greenwich as simply a mark of extraordinary excellence and marvel creation of the architects'.

Participants of the first and seventh FGDs also connoted that, the Maritime Greenwich has potentials to represent both the real facts and presence of Modernisation. This is really a site which can fulfil demand of the heritage tourists. However, in principle, all of the respondents argued that this site is novel and can fascinate tourists from almost every part of the world that supports that MGWHS is becoming a key tourist destination (Hassan \& Iankova, 2012; Hassan \& Rahman, 2015b).

\section{Modernisation}

The process of technology application for modernisation in a heritage site environment was one of the key points to discuss. Technology application for modernisation is a vast phenomenon and for this study, other than imposing narrowed scopes of Modernisation, general views from the tourists were attempted to generate. This process of technology application for modernisation in the Maritime Greenwich had diverse ways and shapes to attract general tourists. Most of the incoming tourists to MGWHS expected that the site would be modernised, in terms of tourist facilities. Respondents $\mathrm{R}_{5}, \mathrm{R}_{7}$, R12 and S9 expected that the site would be modern and technologically improved prior to their visit. On the other side, respondent $S_{3}$ and $S_{4}$ were more optimistic and respondent $S_{2}$ argued that, "in a historically important site, we expect this is modern in terms displaying capacities of its resources'.

Two main areas of technology application for modernisation in the World Heritage Site perspective were explored: the language interpretation and the audio-visual forms of documentary type presentations. However, all of the tourist respondents expressed the demand of technology application for modernisation in heritage tourist sites. They also wanted that modernized ways of interpretations 
were required. However, outgoing respondent S14 opined that, 'MGWHS is in need of applying updated technology for tourist purposes'. The incoming tourist respondent S6 from Nepal had very limited knowledge over English and claimed that, 'if you had proper and vibrant ways of interpretation in Nepali language that would fulfil main purpose of my visit from a very remote part of the world, where I belong to'. This was echoed in statement of the key informant K1, who expressed his view as, 'we have very good understanding that the demand of different language interpretation is essential. However, due to the limitation of resources, very often we are unable to provide this benefit to majority of the multicultural tourists. We have keen consideration to work on this issue'. In particular, respondent Sio stressed on creating more spaces for technology application in this WHS and argued that, 'the site really requires interpretational technology application for international tourists'. The outgoing tourist respondent S12 from Saudi Arabia emphasised on technology by saying that, 'both audio interpretation and documentary presentation should be made available'.

Outcome of the FGDs four, five, eight and ten with groups of international tourists highlighted the importance of documentary presentation prior to the visit. According to them, this would help to ensure most efficient understanding of the Maritime Greenwich.

These statements support research findings that a site with higher heritage value can have better touristic values (Carnegie \& Mccabe, 2008).

\section{Historic significance}

Historic significance in MGWHS creates as an importance aspect creates interest among the potential tourists. The interests in this regard can be classified into two wider categories: first, the rich historic significance of Greenwich; and second, the historic architectural significance of the MGWHS.

The incoming respondents $\mathrm{R}_{1}, \mathrm{R}_{5}, \mathrm{R} 7, \mathrm{R} 8, \mathrm{R}_{10}, \mathrm{R}_{12}$ and $\mathrm{R}_{14}$ was amazed by the rich historic significance of Greenwich. Respondent R2 was clear in this regard and commented that 'I have heard so much about Greenwich as river port with great historic significance that it was difficult for me to keep waiting to visit'. Respondent R4 also mentioned that 'Greenwich has a long history that is interesting. This is my pleasure to be here to learn the history'. Respondent R3, R6, R9 and R11 were more convinced by the historic architectural significance of the MGWHS. This was reflected in the opinion of R13 who stated that 'The buildings in the MGWHS are really exceptional from the architectural context. These buildings have created historic architectural significance'.

The outgoing respondents $\mathrm{S}_{1}, \mathrm{~S}_{2}, \mathrm{~S}_{3}, \mathrm{~S}_{5}, \mathrm{~S}_{7}, \mathrm{~S}_{9}$ and $\mathrm{S}_{11}$ appeared as happy with their visitation at Greenwich. Respondent $S_{4}$ mentioned that 'I have really learnt a lot from my visit. Descriptions of important historical events are highlighted in many places including the Maritime museum'. Respondent S6 also supported this statement by stating that 'I am really pleased to see the way histories are presented in Greenwich...this is just awesome'. Regarding the historic architectural significance, respondent S8, S10, S13 and S14 were visibly surprised. Respondent S12 argued that 'the buildings are architectural assets and these need proper attention from the historic perspective'. This was echoed by the respondent S14 with the statement that 'I really like the buildings here in MGWHS. These are architecturally unique and represents rich historic architectural significance'.

Summary of findings of the FGDs first, second, third, fourth, fifth, sixth, eighth and tenth also confirmed the historic significance of the MGWHS. 
From the theoretical perspective, MGWHS renders historic significance as these can influence the present as well as help shaping the future (Yung \& Chan, 2011). The site, buildings, events and developments have historic significance on the lens of novelty, applicability, memory, and effects (History Skills, 2020; Northern Ireland Council for Integrated Education, 2020).

\section{Sustainable authenticity and tourism}

Personal observation explored that to majority of the tourists both incoming and outgoing, sustainable authenticity represented uniqueness and a few of them could not even able to fully understand meaning of this term. The incoming tourists were visibly more concerned about sustainable authenticity and historical importance, where the outgoing tourists were more focused on experiences. However, in a real sense, all of the incoming tourists desired to enjoy something that was really novel and would offer them different pattern of experiences. The incoming tourist respondent R9 from New Zealand viewed some videos from the Internet with brief interpretations before her decision to come to see the Maritime Greenwich. Still she was eager to see this site in his own eyes and commented, 'seeing is believing and you can never believe the greatness of the Maritime Greenwich, unless you see this in your own eyes'.

The outgoing respondent $\mathrm{S}_{5}$ from India believed that heritage tourism sites were always authentic, but she could not read the limit exactly where this would make appeal to the tourists. In general, all of the tourists desired the presence of sustainable authenticity in heritage tourism sites. The key informant K1 also viewed this as a reality and argued that, in the current world, without sustainable authenticity heritage tourism would lose its appeal to the general tourists'. Even the key informant K2 believed that, 'in present days the media had strong coverage that usually supports the tourists. They can easily enjoy almost everything of a heritage tourism site simply with a click on any key of the television remote control. Practically, bringing these peoples to the site has been transforming into a huge challenge'. Sustainable authenticity was involved in any touristic experience, particularly when heritage is involved and this was reflected in statement of the outgoing respondent S13 from Denmark who argued that, 'sustainable authenticity is a much desired fact and you can never feel tourism without sustainable authenticity'. However, this respondent failed to clarify the ways he would like to witness the interaction of sustainable authenticity with tourism.

Outcome of the FGD two, three and six highlighted that sustainable authenticity and the application of innovative technology for modernisation can be contradictory when proper planning and implementation procedures are missed. Thus, these FGDs asserted on effective and timely planning for modernisation procedures in MGWHS.

Comments of both of the in-depth interviews and FGDs ensure that sustainable authenticity in MGWHS is rather a newer concept and requires further analysis (Steiner \& Reisinger, 2006; Wang, 1999). There can be tension and conflict between authenticity, sustainability and neo-liberal development but these can be harmonised in MGWHS when proper and effective planning are in place (Carnaffan, 2019).

\section{Sustainable Authenticity Seeking Modern Tourists}

Incoming respondent $\mathrm{R}_{3}$ and $\mathrm{R}_{14}$ from Argentina viewed the concept of heritage tourism as knotted with technological intervention. These respondents expected that several forms of entertainments in a heritage site including projections, audio visual sound systems, and so on might be available in MGWHS that supports the application of technology. Respondent R6 asserted on following the successful examples of Germany in the process of modernising MGWHS. Both of the key respondents $\mathrm{K}_{1}$ and $\mathrm{K}_{2}$ revealed a fact. The key informant $\mathrm{K}_{1}$ argued that, 'we always get huge responses from the tourists when we have any demonstrations on the electronic format of visualization, but we have to follow the set 
guidelines of UNESCO and cannot supersede the policies'. However, the key informant K2 replied that, 'whenever we do something on the most modern visual communication systems, we notice enormous general tourists' participation and that has always been viewed as a success'. Outgoing respondent S2, $\mathrm{S}_{3}, \mathrm{~S}_{7}$ and S8 stressed on maintaining authentic value of MGWHS, while respondent R8 stated that, 'the site is very unique and needs to be kept intact'. Similar statement was offered by respondent Rio as, 'this site is very rare for its architectural resources. Thus, the management needs to be careful and responsible about it'. These two respondents were favouring to concentrate on sustainable authenticity. On the other side, respondents R11, $\mathrm{S}_{5}, \mathrm{~S}_{7}$ and $\mathrm{S}_{9}$ were in support of creating more facilities for tourists that are technology supported. As stated by respondent S11, 'I personally do not see any factional relationship between sustainable authenticity and technology application for modernisation'.

Outcome of FGD nine also supported that technology application for modernisation can meet demands of sustainable authenticity seeking modern tourists.

Most of the heritage tourists in recent days are familiar with numerous forms of technological advancements (MacCannell, 1973). Characteristically, these tourists can be identified as the 'authenticity seeking modern tourists'. This view has managed to found its way through arguments of the respondents. Thus evidently and clearly, most of the tourists in MGWHS were seeking historical excellence and sustainable authenticity with the help of modernised facilities as supported by technology. These statements of respondents clearly attached to scholarly opinions that, a WHS as MGWHS is getting more focused to technology application for experience generation (Guttormsen \& Fageraas, 2011; Lew, 2011). These statements thus approve theoretical analysis that technology can be parallel to sustainable authenticity (Cohen-Hattab \& Kerber, 2004; Conran, 2006; Taylor \& Kirsty, 2006; United Nations Educational, Scientific and Cultural Organization, 2019b).

\section{Conclusion}

Sustainable authenticity and historical excellence as parts of the heritage tourism are inevitable and have typical positive responses on the tourists, in general. However, when the aspects of technology application for modernisation appear, this more obviously attract the attention of tourists from all types. Technology application for modernisation processes covering both tangible and intangible forms have capacity to attract and to maintain the interest of tourists. Technology application for modernisation can have conflicted relationship with both of these aspects and still, cannot be separated from any form of heritage tourism.

Key findings of this research support that, technology application for modernisation purpose can meet demands of identified modern tourist groups that seek authentic. The single and most powerful reason for this is the demand from tourist side. Case of the Maritime Greenwich has also represented the same, where the tourists very often seek and ask for Technology application for modernisation and particularly technological intervention of language interpretation with audio-visual presentations. These are aimed to explore the depth of sustainable authenticity and historical excellence and are getting more prioritized over time and space. In another sense, Technology application for modernisation can have conflict with sustainable authenticity and is simply due to the inappropriate use and mismanagement. Proper use and application of modernised version of technological advancements can positively add diversity and betterment of a heritage tourism site. There has been strong presence of sustainable authenticity seeking modern tourists and this has been experienced from case of the Maritime Greenwich. 
Apart from other relevant forms of tourist facilities like physical establishments, modernized forms of language interpretation with explanation or visualisation of historic artefacts and sustainable authenticity can express effects to retain interests of the heritage tourists. Tourist demands in a World Heritage Site environment are immense and deserve appropriate steps to fulfil, even though guidelines of the UNESCO can appear as a major set of obstacles. These set of guidelines have been prepared to ensure well-being of the site and is worthy of optimum respect. In essence, this was much expected by the tourists that technology application for modernisation interact with the traditional heritage tourism to offer the tourists something really different and unique from those they can view online or on the television.

Managers or the responsible management in a WHS need to learn that tourism in any site with heritage importance and the heritage tourists have been constantly changing their choices and demand patterns based on modernisation. Findings of this research thus can help them formulating and implementing a tourist friendly WHS management protocol.

This research primarily relied on limited number of in-depth interviews, FGDs and literature review. This is rather a limitation to engage the opinions of wider respondents and opinion leaders. Authenticity is a broad term that can hardly be narrowed down and restricted followed by the intervention of innovative technologies. The number of in-depth interviews and FGDs could possibly be increased in future research studies supported by survey research to cover both authenticity and the application of innovative technology from a comprehensive outlook. More engagement of empirical evidences could possibly support findings of this research and this remains the area of further research.

\section{References}

Agyeiwaah, E., McKercher, B., \& Suntikul, W. (2017). Identifying core indicators of sustainable tourism: A path forward? Tourism Management Perspective, 24, 26-33.

Albayrak, T., \& Caber, M. (2019). Examining the relationship between tourist motivation and satisfaction by two competing methods. Tourism Management, 69, 201-213.

Alberts, H.C., \& Hazen, H.D. (2010). Maintaining sustainable authenticity and integrity in cultural World Heritage Sites. Geographical Review, 100(1), 56-73.

Bec, A., Moyle, B., Timms, K., Schaffer, V., Skavronskaya, \& Little, C. (2019). Management of immersive heritage tourism experiences: A conceptual model. Tourism Management, 72, 117-120.

Bowitz, E., \& Ibenholt, K. (2009). Economic impacts of cultural heritage: Research and perspectives. Journal of Cultural Heritage, 10, 1-8.

Carnaffan, J, (2019). Authenticity and sustainability in responsibility tourism. Available online: http://bit.ly/jYv2M (accessed on 8 June 2019).

Carnegie, E., \& Mccabe, S. (2008). Re-enactment events and tourism: Meaning, sustainable authenticity and identity. Current Issues in Tourism, 11(4), 349-368.

Chhabra, D. (2008). Positioning museums on an authenticity continuum. Annals of Tourism Research, $3(1), 427-447$.

Cohen, E. (2001). Thailand in touristic transition. In T. C. Chuang and T. C. Chin (Eds.), Interconnected worlds: Southeast Asian tourism in the 21st century. Singapore: Singapore University Press.

Cohen-Hattab, K., \& Kerber, J. (2004). Literature, cultural identity and the limits of sustainable authenticity: A composite approach. International Journal of Tourism Research, 6, 57-73.

Conran, M. (2006). Beyond sustainable authenticity: Exploring intimacy in the touristic encounter in Thailand. Tourism Geographies, 8(3), 274-285.

English Heritage. (2008). Conservation Principles, Policies and Guidance for the Sustainable Management of the Historic Environment. London: English Heritage. 
Giddens, A. (1991). Modernity and self-identity: Self and society in the late modern age; Polity Press: London, 1991.

Guttormsen, T. S., \& Fageraas, K. (2011). The social production of 'attractive sustainable authenticity' at the World Heritage Site of Røros, Norway. International Journal of Heritage Studies, 17(5), 442462.

Handler, R., \& Saxton, W. (1988). Dyssimulation: Reflexivity, Narrative, and the Quest for Authenticity in 'Living History'. Cultural Anthropology, 3(3), 242-26o.

Harrison, D., \& Hitchock, M. (2005). The politics of World Heritage: Negotiating tourism and conservation; Channel View Publications: Clevedon.

Hassan, A., \& Iankova, K. (2012). Strategies and Challenges of Tourist Facilities Management in the World Heritage Site: Case of the Maritime Greenwich, London. Tourism Analysis, 17(6), 791-803.

Hassan, A., \& Rahman, M. (2015a). World Heritage Site as a Label in Branding a Place. Journal of Cultural Heritage Management and Sustainable Development, 5(3), 210-223.

Hassan, A., \& Rahman, M. (2015b). Macromarketing Perspective in Promoting Tourism: The Case of the Buddhist Vihara at Paharpur. Tourism Spectrum, 1(2), 13-19.

History Skills (2020). Historical significance. Available online: https://www.historyskills.com/historicalknowledge/significance/ (accessed on 18 January 2020).

Jokilehto, J. (2006). Considerations on sustainable authenticity and integrity in world heritage context. City \& Time, 2, 1-16.

Labadi, S. (2007). World Heritage: Challenges for the millennium. UNESCO: Paris, France, 2007.

Larsen, K.E. (1995). The Test of Sustainable authenticity" and national heritage legislation. Paper presented at the Nara Conference on Sustainable authenticity in Relation to the World Heritage Convention. Nara, Japan.

Lew, A. A. (2011). Understanding experiential sustainable authenticity through the best tourism places. Tourism Geographies, 13(4), 570-575.

Lisagor, K., \& Hansen, H. (2008). Disappearing destinations. New York, NY: Vintage Books.

MacCannell, D. (1973). Staged sustainable authenticity: Arrangements of social space in tourist settings. American Journal of Sociology, 79(3), 589-603.

MacCannell, D. (1976). The tourist: A new theory of the leisure class; New York, NY: Schocken.

Martin, K. (2010). Living pasts: Contested Tourism Authenticities. Annals of Tourism Research, 37(2), 537-554.

McKercher, B., \& du Cros, H. (2002). Cultural tourism: The partnership between tourism and cultural heritage management. Binghamton: Haworth Hospitality Press.

Merriam, S.B. \& Grenier, R.S. (2019) (Eds.). Qualitative Research in Practice: Examples for Discussion and Analysis. San Francisco, CA: John Wiley \& Sons.

Millar, S. (1989). Heritage management for heritage tourism. Tourism Management, 10, 9-14.

Moscardo, G. M., \& Pearce, P. L. (1986). Historic theme parks: An Australian experience in authenticity. Annals of Tourism Research, 13, 467-479.

Nguyena, T.N.T.; Young, T.; Johnson, P., \& Wearing, S. (2019). Conceptualising networks in sustainable tourism development. Tourism Management Perspective, 32, 100575.

Northern Ireland Council for Integrated Education (2020). Historical significance. Available online: http://facingthepastshapingthefuture.com/teacher-guidance/teaching-learningstrategies/history/historical-significance/ (accessed on 18 January 2020).

Pack, S. (2008). Tourism, modernization, and difference: A twentieth-century Spanish Paradigm. Sport in Society, 11(6), 657-672.

Park, E., Choi-B-K., \& Lee, T. J. (2019). The role and dimensions of authenticity in heritage tourism. Tourism Management, 74, 99-109.

Pearce, P. (1982). Perceived changes in holiday destinations. Annals of Tourism Research, 9(2), 145-164. 
Peter, J. P., \& Olson, J. C. (1999). Consumer behavior and marketing strategy. Chicago, CA: Irwin McGraw- Hill.

Pickel-Chevalier, S. (2019). Tourism and equine heritage in France: the case study of the Cadre noir de Saumur and the Vendée Stud. Current Issues in Tourism, DOI: 10.1080/13683500.2019.1706459

Ram, Y., Björk, P., \& Weidenfeld, A. (2016). Sustainable authenticity and place attachment of major visitor attractions. Tourism Management, 52, 110-122.

Ramkissoon, H. (2015). Sustainable authenticity, satisfaction, and place attachment: A conceptual framework for cultural tourism in African island economies. Development Southern Africa, 32(3), 292-302.

Reisinger, Y., \& Steiner, C. (2006). Reconceptualising object sustainable authenticity. Annals of Tourism Research, 33(1), 65-86.

Rickley-Boyd, J.M. (2012). Authenticity \& aura: A Benjaminian Approach to Tourism. Annals of Tourism Research, 39(1), 269-289.

Ross, D. (2020): Towards meaningful co-creation: a study of creative heritage tourism in Alentejo, Portugal, Current Issues in Tourism. DOI: 10.1080/13683500.2020.1782355

Spooner, B. (1986). Weavers and dealers: authenticity and oriental carpets. In A. Appadurai (ed.), The Social Life of Things: Commodities in Cultural Perspective. Cambridge: Cambridge University Press, pp. $195^{-235}$.

Steiner, C. J., \& Reisinger, Y. (2006). Understanding existential sustainable authenticity. Annals of Tourism Research, 33, 299-318.

Tan, S. K., Lim, H. H., Tan, S. H., \& Kok, Y. S. (2020). A cultural creativity framework for the sustainability of intangible cultural heritage. Journal of Hospitality \& Tourism Research, 44(3), 439-471.

Tasci, A. D. A., \& Knutson, B. J. (2004). An argument for providing sustainable authenticity and familiarity in tourism destinations. Journal of Hospitality and Leisure Marketing, 11(1), 85-109.

Taylor, K., \& Kirsty, K. (2006). Cultural landscapes in Asia-Pacific: Potential for filling World Heritage gaps. International Journal of Heritage Studies, 12(3), 267-282.

The National Maritime Museum (2019). Visit. Available online: http://bit.ly/WF7Ufc (accessed on 8 June 2019).

United Nations Educational, Scientific and Cultural Organization (UNESCO). (2019a). The World Heritage Site. Available online: http://bit.ly/jYv2M (accessed on 8 June 2019a).

United Nations Educational, Scientific and Cultural Organization (UNESCO) (2019b). Maritime Greenwich. Available online: http://bit.ly/18E8Y7i (accessed on 8 June 2019b).

Wang, N. (1999). Rethinking sustainable authenticity in tourism experience. Annals of Tourism Research, 26(2), 349-370.

Yung, E.H.K. \& Chan, E.H.W. (2011). Problem issues of public participation in built-heritage conservation: Two controversial cases in Hong Kong. Habitat International, 35(3), 457-466.

Received: 11/10/2019

Accepted: 18/o9/2020

Coordinating editor: Martina Gonzalez-Gallarza 